\title{
SISTEM INFORMASI PENJUALAN PRODUK PERTANIAN PADA BADAN USAHA MILIK DESA (BUMDES) PERNEK
}

\author{
Eri Sasmita Susanto ${ }^{1^{*}}$, Mariati $^{2}$ \\ ${ }^{1,2}$ Teknik Informatika, Universitas Teknologi Sumbawa \\ email: eri.sasmita.susanto@uts.ac.id*
}

\begin{abstract}
Abstrak: Proses penjualan dengan menggunakan teknologi informasi dikenal dengan istilah Electronic-Commerce. Badan Usaha Milik Desa (BUMDes) Pernek Kecamatan Moyo merupakan salah satu instansi pemerintah yang dikelolah oleh masyarakat dan pemerintah desa dalam upaya memperkuat perekonomian desa dan dibentuk berdasarkan kebutuhan dan potensi desa. BUMDes Pernek Kecamatan Moyo Hulu memiliki beberapa unit usaha yang dikembangkan salah satunya yaitu penjualan produk pertanian. Dalam menangani proses kegiatan penjualan dan promosi produk pertanian masih dilakukan secara manual. Berdasarkan hal tersebut, maka diperlukan sebuah web penjualan online sebagai media sarana untuk mendukung kinerja petugas dalam melakukan kegiatan penjualan dan promosi produk serta dalam pengelolaan data penjualan produk pertanian di BUMDes Pernek. Penelitian ini termasuk ke dalam penelitian kualitatif yang bersifat deskriftif.
\end{abstract}

Kata Kunci : Bumdes, Penjualan, Produk, Sistem, Informasi

Abstract: The sales process using information technology is known as Electronic-Commerce. Village-Owned Enterprises (BUMDes) Pernek Moyo District is one of the government agencies managed by the community and village government in an effort to strengthen the village economy and is formed based on the needs and potential of the village. BUMDes Pernek Moyo Hulu Sub-district has several business units which are developed, one of which is the sale of agricultural products.In handling the process of selling and promoting agricultural products, it is still done manually. Based on this, an online sales web is needed as a media to support the performance of officers in conducting product sales and promotion activities as well as in the management of sales data for agricultural products in BUMDes Pernek.This research belongs to descriptive qualitative research.

Keywords : Bumdes, Sales, Products, System, Information

\section{PENDAHULUAN}

Teknologi informasi pada era globalisasi saat ini yang semakin maju dan berkembang dapat dimanfaatkan dalam menunjang pekerjaan manusia termasuk pada bidang pemerintahan. Salah satu bentuk pemerintahan yang baik dapat dilihat dari pelayanan-pelayanan yang diberikan kepada publik yang sudah dilakukan secara efektif dan efesien. Bentuk pelayanan publik yang sudah memanfaatkan teknologi informasi dalam ruang lingkup pemerintahan dikenal dengan istilah ElectronicGovernment. Keberadaan teknologi informasi juga membawa perubahan yang cukup signifikan dibidang ekonomi pada kegiatan penjualan. Proses penjualan dengan mengunakan teknologi informasi dikenal dengan istilah Electronic-Commerce. Penjualan merupakan kegiatan yang dilakukan oleh sebuah organisasi atau perusahaan untuk menghasilkan keuntungan. Dengan adanya teknologi informasi pada proses penjualan atau Electronic-Commerce, interaksi dilakukan tidak perlu hadir secara fisik, dapat memperluas peluang pangsa pasar, mempermudah proses penjualan dan promosi produk serta dapat mempermudah konsumen dalam mengetahui informasi produk secara detail seperti manfaat, harga, dan stok produk dan dalam pengolahan data penjualan dapat dilakukan lebih efektif dan efesien.

BUMDes Pernek Kecamatan Moyo Hulu memiliki beberapa unit usaha yang dikembangkan salah satunya yaitu penjualan produk pertanian, dikarenakan hampir seluruh masyarakat Desa Pernek berprofesi sebagai petani sehingga dapat memenuhi kebutuhan petani serta dijadikan peluang oleh pemerintah desa untuk meningkatkan penghasilan BUMDes. Dalam menangani proses kegiatan penjualan dan promosi produk pertanian masih dilakukan secara manual. Penjualan dan promosi produk mencakup areal yang terbatas yaitu hanya diwilayah Desa Pernek. Pengenalan produk terhadap konsumen dilakukan dengan cara mendatangi pihak BUMDes untuk mengetahui informasi produk secara detail, serta dalam melakukan proses pengolahan dan penyimpanan data penjualan produk dikelolah dengan mengunakan Microsoft Excel dan juga catatan buku. Dalam pegolahan tersebut pernah terjadi kerancuan atau jumlah produk yang terjual tidak sesuai dengan jumlah penghasilan yang didapat sehingga pegawai BUMDes harus ganti rugi agar jumlah produk yang terjual dan jumlah penghasilan harus sesuai.

Berdasarkan hal tersebut, maka diperlukan sebuah web penjualan online sebagai media sarana untuk mendukung kinerja petugas dalam melakukan kegiatan penjualan dan promosi produk serta dalam pengelolaan data penjualan produk pertanian di BUMDes Pernek. Oleh karena itu, penulis mencoba membuat Sistem Informasi Penjualan Produk Pertanian Pada Badan Usaha Milik Desa (BUMDes) Pernek Kecamatan Moyo Hulu Berbasis Web.

Harapan dari penulis adalah aplikasi ini dapat berperan dalam mendukung dan meningkatkan kinerja pegawai agar terciptanya pelayanan publik yang baik, pengelolaan data penjualan yang lebih 
efektif dan efesien serta penjualan dan promosi produk pertanian pada BUMDes Pernek Kecamatan Moyo Hulu dapat dilakukan dengan mudah kepada konsumen.

\section{TINJAUAN PUSTAKA}

Penelitian yang terkait sistem informasi penjualan telah banyak dilakukan termasuk pada penelitian yang berjudul Sistem Informasi Penjualan Pembelian Dan Persediaan Barang Pada Toko Yunika Berbasis Dekstop (Program Studi Sistem Informasi, Fakultas Teknik Dan Ilmu Komputer, Universitas Komputer Indonesia, Bandung, 2015) [1]. Pada penelitian ini Muhamad Febrian Mulawarman membuat sistem informasi yang dapat memudahkan proses penjualan, pembelian, dan persediaan barang pada Toko Yunita, metode perancangan menggunakan data flow diagram (dfd), dan teknik pengujian mengunakan metode black box testing.

Sistem (system) dapat didefinisikan dengan pendekatan prosedur dan dengan pendekatan komponen. Dengan pendekatan prosedur, sistem dapat didefinisikan sebagai kumpulan dari prosedurprosedur yang mempunyai tujuan tertentu [2]. Informasi adalah hasil pemrosesan, manipulasi, dan perorganisasian/penataan dari sekelompok data yang menjadi nilai pengetahuan bagi penggunanya [3].

Sistem informasi adalah kombinasi prosedur kerja, informasi, orang, dan teknologi informasi yang diorganisasikan untuk mencapai tujuan dalam organisasi [4].

\section{METODE}

\section{Metode Penelitian}

Adapun alur penelitian yang dilakukan penulis pada penelitian Sistem Informasi Penjualan Produk Pertanian Pada Bada Usaha Milik Desa (BUMDes) Pernek Kecamatan Moyo Hulu Berbasis Web adalah sebagai berikut:

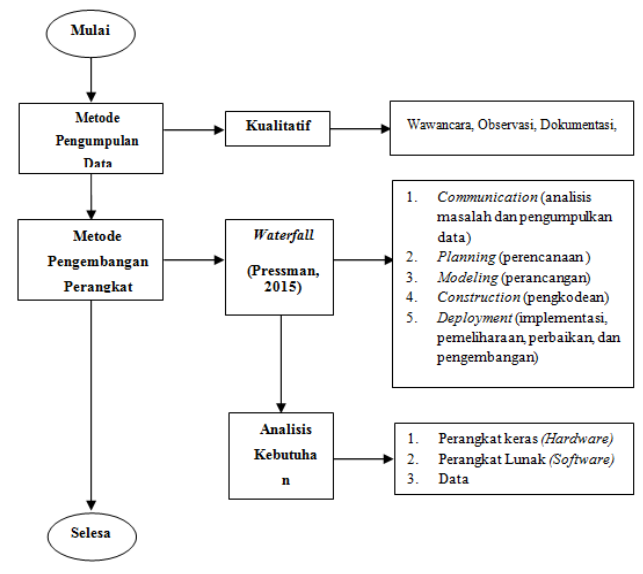

Gambar 1. Alur Penelitian

Pada gambar di atas adapun alur penulis dalam melakukan perancangan aplikasi ini dari awal melakukan penelitian hingga akhir penelitian serta tahapan-tahapan yang dilakukan seperti yang tertera pada gambar. Penelitian ini termasuk ke dalam penelitian kualitatif yang bersifat deskriftif. Karena dalam penelitian ini penulis melakukan penelitian dan memecahkan masalah dengan menggambarkan keadaan peneliatian berdasarkan fakta-fakta yang ada. Berikut adalah penjelasan dari setiap tahapantahapan gambar di atas :

1. Mulai

Pada tahap ini penulis mulai melakukan penelitian di Badan Usaha Milik Desa (BUMDes) Pernek Kecamatan Moyo Hulu. Dan ditemukan masalah pada proses penjualan seperti yang telah dijelaskan sebelumnya serta solusi yang telah ditawarkan.

2. Metode Penumpulan Data

Pada tahap ini penulis mengumpulkan datadata berdasarkan masalah yang telah ditemukan pada awal penelitian. Metode yang digunakan dalam penelitian ini adalah metode penelitian kualitatif. Adapun tujuan dari penelitian kualitatif ialah untuk memperoleh gambaran seutuhnya mengenai suatu hal menurut pandangan manusia yang diteliti. Penelitian kualitatif berhubungan dengan ide, persepsi, pendapat, atau kepercayaan orang yang diteliti yang kesemuanya tidak dapat diukur dengan angka. Sedangkan metode pengumpulan data dalam penelitian ini meliputi wawancara, observasi, dokumentasi dan studi pustaka.

3. Metode Pengembangan Perangkat Lunak

Pada tahap ini penulis penulis mulai melakukan pengembangan perangkat lunak berdasarkan analisis masalah serta kebutuhan data-data yang telah dikumpulkan. Pada penelitian ini metode pengembangan perangkat lunak yang digunakan yaitu metode pengembangan waterfall menurut Pressman (2015:42), yang memiliki lima tahap yaitu communication, planning, modeling, contruction, dan deployment. Pada tahap ini penulis juga melakukan analisis kebutuhan perangkat seperti perangkat keras, perangkat lunak, dan data yang dibutuhkan dalam membangun sistem.

4. Selesai

Tahap ini merupakan akhir dari penelitian yang menandakan bahwa penelitian telah selesai dilakukan.

\section{Metode Pengumpulan Data}

Metode pengumpulan data dalam penelitian ini meliputi wawancara, observasi, dan dokumentasi :

1. Wawancara

Peneliti datang langsung ke Objek penelitian, menanyakan kekurangan, keadaan, dan permasalahan pada objek penelitian

2. Observasi

Melakukan pengumpulan data berupa data penjualan produk

3. Dokumentasi 
Melakukan Dokumentasi berupa foto, surat ijin penelitian dan lain - lain.

\section{HASIL DAN PEMBAHASAN}

\section{Alur Kerja Sistem Berjalan}

Berikut adalah alur sistem yang berjalan pada saat ini seperti pada gambar dibawah ini :

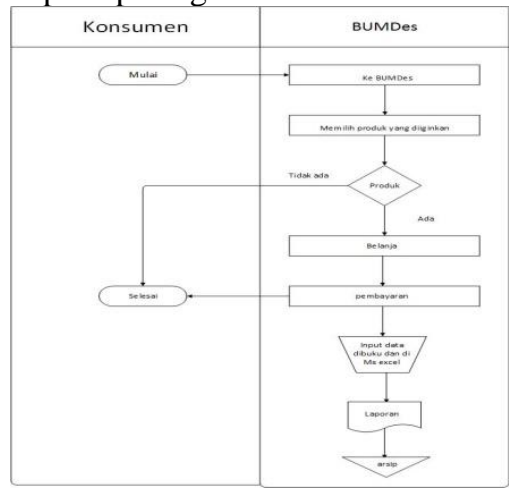

Gambar 2. Alur Kerja Sistem Berjalan

\section{Alur Kerja Yang Diusulkan}

Berikut adalah sistem yang diusulkan penulis pada BUMDes Pernek Kecamatan Moyo Hulu dapat dilihat seperti pada gambar dibawah ini:

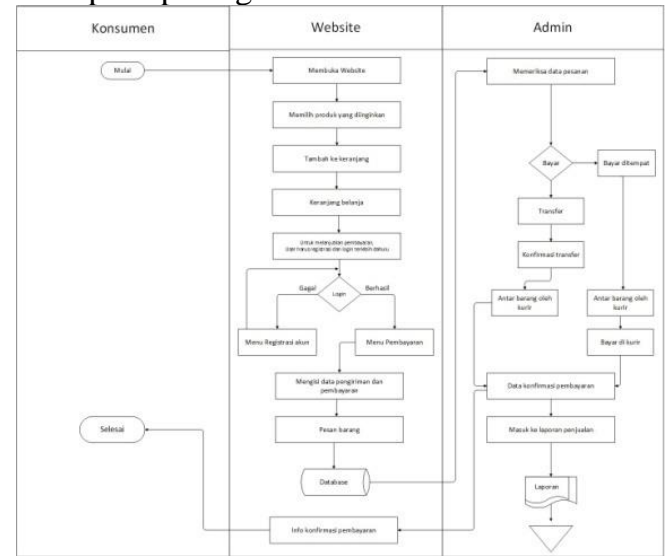

Gambar 3. Alur Kerja Sistem Yang Diusulkan

\section{Use Case Diagram}

1. Use Case Diagram User

Berikut adalah use case diagram user dari sistem informasi yang telah dibuat:

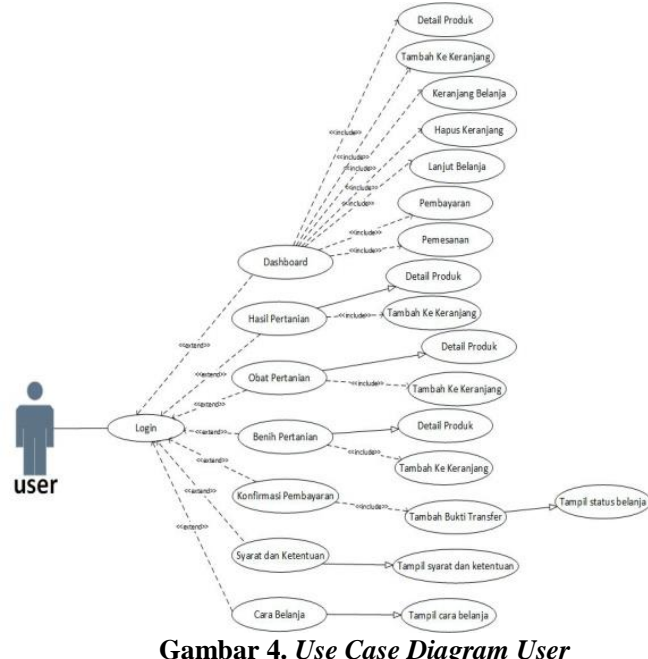

2. Use Case Diagram Admin

Berikut adalah use case diagram admin dari sistem informasi yang telah dibuat:

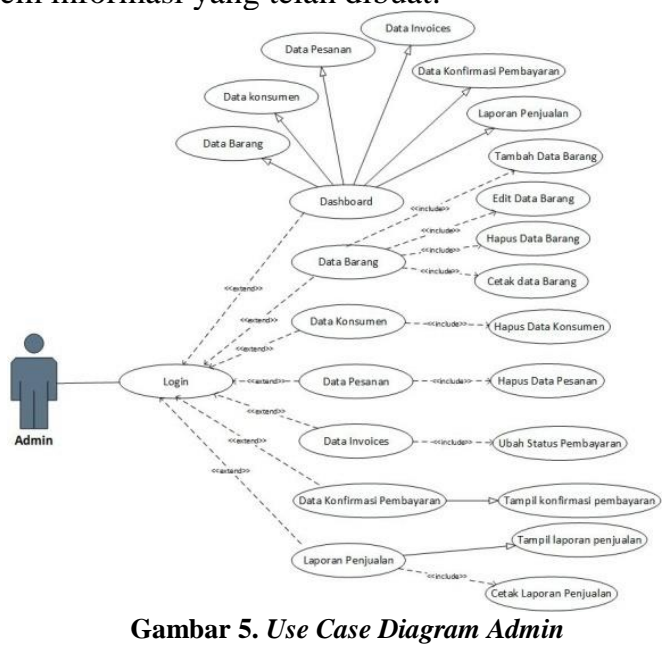

Class Diagram

Berikut adalah class diagram dari sistem yang di buat :

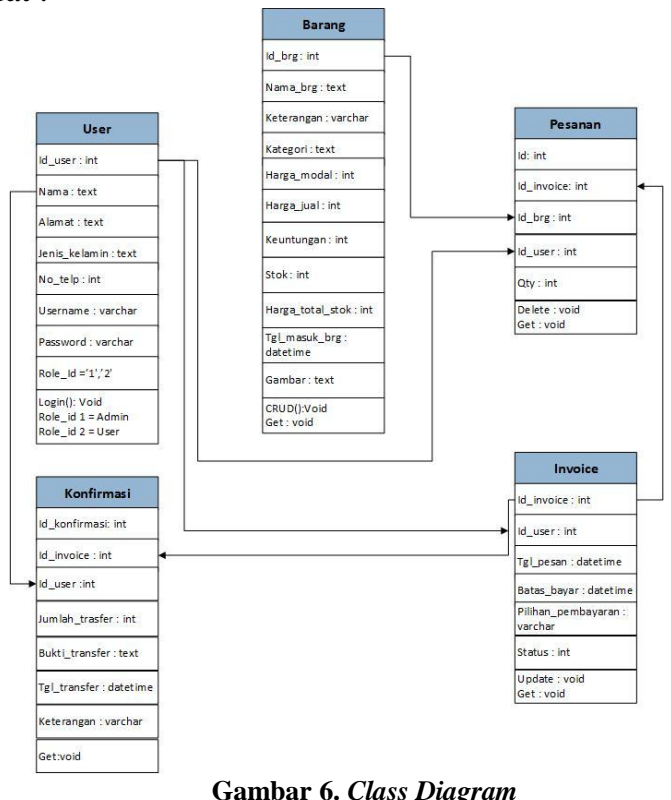




\section{Perancangan Interface}

1. Rancangan Interface Form Login

Berikut adalah rancangan interface Form Login :

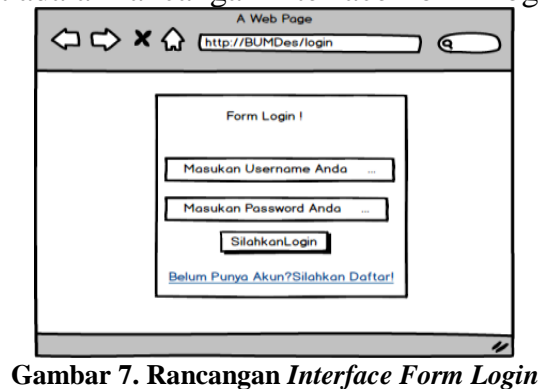

2. Rancangan Interface Form Registrasi Berikut adalah rancangan Interface Form Registrasi :

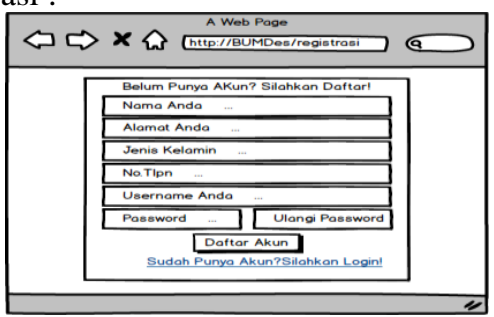

Gambar 8. Rancangan Interface Form Registrasi

3. Rancagnan Interface Dashboard Admin Berikut adalah rancangan interface dashboard admin :

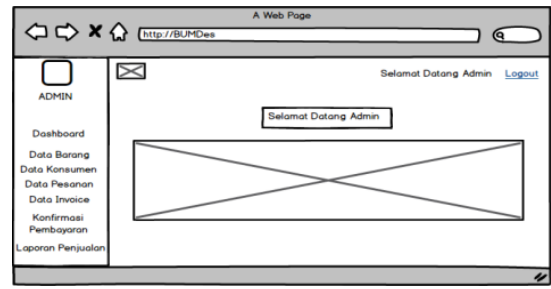

Gambar 9. Rancangan Interface Dashboard admin

4. Rancangan Interface Dashboard User Berikut adalah rancangan interface dashboard user :

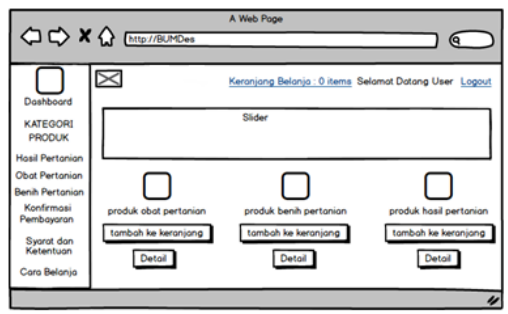

Gambar 10. Rancangan Interface Dashboard User

\section{Pengujian Perangkat Lunak}

Pengujian Sistem Informasi Penjualan Produk Pertanian Pada Badan Usaha Milik Desa (BUMDes) Pernek Kecamatan Moyo Hulu Berbasis Web ini menggunakan pengujian black box. Pengujian black box berfokus pada persyaratan fungsional perangkat lunak. Berikut adalah hasil pengujian dari sistem yang dibuat :
1. Pengujian Halaman Admin

Berikut adalah hasil pengujian halaman admin :

Tabel 1. Pengujian Halaman Admin

\begin{tabular}{|c|c|c|c|}
\hline No. & $\begin{array}{c}\text { Skenario } \\
\text { Pengujian }\end{array}$ & $\begin{array}{c}\text { Hasil yang } \\
\text { Diharapkan }\end{array}$ & Kesimpulan \\
\hline 1. & $\begin{array}{l}\text { Halaman } \\
\text { dashboard } \\
\text { admin }\end{array}$ & $\begin{array}{l}\text { Halaman dashboard } \\
\text { admin akan tampil } \\
\text { ketika sistem } \\
\text { menerima akses } \\
\text { Login sebagai admin } \\
\text { menu didalamnya } \\
\text { yaitu data barang, } \\
\text { data konsumen, data } \\
\text { pesanan, data } \\
\text { invoice, data } \\
\text { konfirmasi dan } \\
\text { pebayaran, daporan penjualan. } \\
\text { lan }\end{array}$ & Sukses \\
\hline 2. & $\begin{array}{l}\text { Halaman data } \\
\text { barang }\end{array}$ & $\begin{array}{l}\text { Manampilkan data } \\
\text { barang dan terdapat } \\
\text { button cari, button } \\
\text { tambah barang, } \\
\text { button edit, button } \\
\text { hapus, dan button } \\
\text { cetak laporan. }\end{array}$ & Sukses \\
\hline 3. & $\begin{array}{l}\text { Button } \\
\text { tambah } \\
\text { barang }\end{array}$ & $\begin{array}{l}\text { Menambahkan data } \\
\text { barang. }\end{array}$ & Sukses \\
\hline 4. & $\begin{array}{lr}\text { Button } & \text { hapus } \\
\text { pada } & \text { data } \\
\text { barang } & \end{array}$ & \begin{tabular}{llr}
\multicolumn{2}{l}{ Menghapus } & data \\
barang yang & di \\
inginkan. & &
\end{tabular} & Sukses \\
\hline 5. & $\begin{array}{lr}\begin{array}{l}\text { Button } \\
\text { pada }\end{array} & \text { datit } \\
\text { barang } & \\
\end{array}$ & $\begin{array}{l}\text { Mengedit data barang } \\
\text { yang di inginkan. }\end{array}$ & Sukses \\
\hline 6. & $\begin{array}{l}\text { Button cetak } \\
\text { laporan pada } \\
\text { data barang }\end{array}$ & $\begin{array}{ll}\text { Mencetak laporan } \\
\text { data barang. }\end{array}$ & Sukses \\
\hline 7. & $\begin{array}{l}\text { Halaman data } \\
\text { konsumen }\end{array}$ & $\begin{array}{l}\text { Menampilkan data } \\
\text { admin dan data } u \text { ser. }\end{array}$ & Sukses \\
\hline 8. & $\begin{array}{l}\text { Hapus data } \\
\text { kondumen }\end{array}$ & $\begin{array}{l}\text { Menghapus data } \\
\text { konsumen. }\end{array}$ & Sukses \\
\hline 9. & $\begin{array}{l}\text { Halaman data } \\
\text { pesanan }\end{array}$ & $\begin{array}{l}\text { Menampilkan data } \\
\text { pesana dari konsumen } \\
\text { dan terdapat button } \\
\text { hapus. }\end{array}$ & Suskes \\
\hline 10. & $\begin{array}{lr}\begin{array}{l}\text { Button } \\
\text { pada }\end{array} & \text { data } \\
\text { pesanan } & \\
\end{array}$ & $\begin{array}{lr}\text { Menghapus } & \text { data } \\
\text { pesanan } & \text { yang } \\
\text { diinginkan. } & \\
\end{array}$ & Sukses \\
\hline 11. & $\begin{array}{l}\text { Halaman data } \\
\text { invoices }\end{array}$ & $\begin{array}{l}\text { Menampilkan data } \\
\text { invoices }\end{array}$ & Sukses \\
\hline 12. & $\begin{array}{l}\text { Halaman } \\
\text { konfirmasi } \\
\text { pembayaran }\end{array}$ & $\begin{array}{l}\text { Menampilkan } \\
\text { konfirmasi } \\
\text { pembayaran dan } \\
\text { menambah } \\
\text { keterangan pesanan. }\end{array}$ & Suskes \\
\hline 13. & $\begin{array}{l}\text { Halaman } \\
\text { laporan } \\
\text { penjualan }\end{array}$ & $\begin{array}{l}\text { Menampilkan laporan } \\
\text { penjualan, dan } \\
\text { terdapat button cari } \\
\text { dan button cetak } \\
\text { laporan. }\end{array}$ & Sukses \\
\hline 14. & $\begin{array}{l}\text { Button cetak } \\
\text { laporan } \\
\text { penjualan }\end{array}$ & $\begin{array}{lr}\text { Mencetak } & \text { data } \\
\text { laporan } & \text { penjualan } \\
\text { berdasarkan tanggal. }\end{array}$ & Sukses \\
\hline
\end{tabular}

2. Pengujian Halaman User

Berikut adalah hasil pengujian halaman User: 
Tabel 2. Pengujian Halaman User

\begin{tabular}{|c|c|c|c|}
\hline No. & $\begin{array}{c}\text { Skenario } \\
\text { Pengujian }\end{array}$ & $\begin{array}{c}\text { Hasil yang } \\
\text { Diharapkan }\end{array}$ & Kesimpulan \\
\hline 1. & $\begin{array}{l}\text { Halaman } \\
\text { dashboard } \\
\text { user }\end{array}$ & \begin{tabular}{lr}
\multicolumn{3}{l}{ Halaman dashboard } \\
user akan & tampil \\
ketika & sistem \\
menerima & akses \\
Login sebagai & User, \\
dan menampilkan & \\
beberapa & menu \\
didalamnya yaitu & hasil pertanian, obat \\
pertanian, & benih \\
pertanian, & \\
konfirmasi & \\
pembayaran, syarat \\
dan ketentuan, dan \\
cara belanja.
\end{tabular} & Sukses \\
\hline 2. & $\begin{array}{l}\text { Button detail } \\
\text { produk }\end{array}$ & $\begin{array}{l}\text { Manampilkan detail } \\
\text { produk dan terdapat } \\
\text { button tambah } \\
\text { keranjang dan button } \\
\text { kembali untuk } \\
\text { kembali ke halaman } \\
\text { dashboad user. }\end{array}$ & Sukses \\
\hline 3. & $\begin{array}{l}\text { Button } \\
\text { tambah ke } \\
\text { keranjang }\end{array}$ & $\begin{array}{l}\text { Menambahkan } \\
\text { produk ke keranjang } \\
\text { belanja sehingga di } \\
\text { keranjang belanja } \\
\text { terdapat jumlah } \\
\text { barang yang di } \\
\text { tambahkan ke } \\
\text { keranjang. }\end{array}$ & Sukses \\
\hline 4. & $\begin{array}{l}\text { Button detail } \\
\text { keranjang } \\
\text { belanja }\end{array}$ & \begin{tabular}{lr}
\multicolumn{3}{l}{ Menampilkan semua } \\
produk yang telah \\
ditambahkan ke \\
keranjang \\
terdapat dan \\
hapus keranjang, \\
button lanjut belanja, \\
dan button \\
pembayaran.
\end{tabular} & Sukses \\
\hline 5. & $\begin{array}{l}\text { Button hapus } \\
\text { keranjang }\end{array}$ & $\begin{array}{l}\text { Menghapus semua isi } \\
\text { keranjang belanja. }\end{array}$ & Sukses \\
\hline 6. & $\begin{array}{l}\text { Button lanjut } \\
\text { belanja }\end{array}$ & $\begin{array}{l}\text { Menampilkan } \\
\text { halaman dashboard } \\
\text { user. }\end{array}$ & Sukses \\
\hline 7. & $\begin{array}{l}\text { Button } \\
\text { pembayaran }\end{array}$ & $\begin{array}{l}\text { Menampilkan jumlah } \\
\text { pesanan, total bayar, } \\
\text { dan } \\
\text { pembayaran } \\
\text { nantinta } \\
\begin{array}{lr}\text { yang } \\
\text { tersimpan di } \\
\text { pesanan. }\end{array} \\
\text { tabel } \\
\end{array}$ & Sukses \\
\hline 8. & $\begin{array}{l}\text { Button } \\
\text { pembayaran } \\
\text { proses } \\
\text { pesanan } \\
\end{array}$ & $\begin{array}{l}\text { Menampilkan pesan } \\
\text { bahwa pesanan akan } \\
\text { segera diproses. }\end{array}$ & Suskes \\
\hline 9. & $\begin{array}{l}\text { Hasil } \\
\text { Pertanian }\end{array}$ & $\begin{array}{ll}\text { Menampilkan } & \text { jenis } \\
\text { produk } & \text { hasil } \\
\text { pertanian. } & \\
\end{array}$ & Sukses \\
\hline 10. & $\begin{array}{l}\text { Obat } \\
\text { Pertanian }\end{array}$ & $\begin{array}{lr}\text { Menampilkan } & \text { jenis } \\
\text { produk } & \text { obat } \\
\text { pertanian. } & \\
\end{array}$ & Sukses \\
\hline 11. & $\begin{array}{l}\text { Benih } \\
\text { Pertanian }\end{array}$ & $\begin{array}{lr}\text { Menampilkan } & \text { jenis } \\
\text { produk } & \text { benih } \\
\text { pertanian. } & \end{array}$ & Sukses \\
\hline 12. & $\begin{array}{l}\text { Halaman } \\
\text { status } \\
\text { pembayaran }\end{array}$ & $\begin{array}{ll}\text { Menampilkan } & \text { status } \\
\text { konfirmasi } & \\
\text { pembayaran } & \text { pada } \\
\text { user. } & \\
\end{array}$ & Sukses \\
\hline
\end{tabular}

\begin{tabular}{|c|l|l|l|}
\hline 13. & $\begin{array}{l}\text { Halaman } \\
\text { konfirmasi } \\
\text { pembayaran }\end{array}$ & $\begin{array}{l}\text { Menampilkan } \\
\text { konfirmasi } \\
\text { pembayaran pada } \\
\text { user untuk meng- } \\
\text { input rakti } \\
\text { pembayaran dan } \\
\text { tanggal transfer jika } \\
\text { memilih pembayaran } \\
\text { via transfer, akan } \\
\text { tetapi jika memilih } \\
\text { pembayaran ditempat } \\
\text { maka halaman ini } \\
\text { bisa diabaikan. }\end{array}$ & \\
\hline 14. & $\begin{array}{l}\text { Halaman } \\
\text { syarat dan } \\
\text { ketentuan }\end{array}$ & $\begin{array}{l}\text { Menampilkan syarat } \\
\text { dan ketentuan dalam } \\
\text { mengakses situs } \\
\text { website. }\end{array}$ & Sukses \\
\hline 15. & $\begin{array}{l}\text { Halaman cara } \\
\text { belanja }\end{array}$ & $\begin{array}{l}\text { Menampilkan cara } \\
\text { belanja pada situs } \\
\text { website. }\end{array}$ & Sukses \\
\hline
\end{tabular}

\section{KESIMPULAN DAN SARAN}

\section{Kesimpulan}

Berdasarkan hasil penelitian pada Badan Usaha Milik Desa (BUMDes) Pernek Kecamatan Moyo Hulu Kabupaten Sumbawa tentang Penjualan Produk Pertanian penulis telah berhasil merancang dan membangun Sistem Informasi Penjualan Produk Pertanian Pada Badan Usaha Milik Desa (BUMDes) Pernek Kecamatan Moyo Hulu Berbasis Web dengan mengunakan metode pengembangan Waterfall, perancangan Unifed Modeling Languange (UML), bahasa pemrograman PHP, database MySQL dan menghasilkan sistem yang telah diuji dengan mengunakan metode Black Box Testing dan sesuai seperti yang diharapkan. Dengan demikian dapat digunakan oleh pihak BUMDes Pernek dalam melakukan penjualan produk pertanian dan pengolaan data penjualan produk pertanian serta dapat meningkatkan penghasilan BUMDes Pernek.

\section{Saran}

Berdasarkan kesimpulan yang telah diuraikan diatas, adapun saran yang dapat penulis berikan untuk pengembangan dan perbaikan sistem kedepannya yaitu penambahan fitur chating untuk user dan admin serta desain dapat dibuat menjadi lebih menarik.

\section{DAFTAR PUSTAKA}

1]Mulawarman, Muhamad Febrian. (2015). "Sistem Informasi Penjualan Pembelian Dan Persediaan Barang Pada Toko Yunika Berbasis Dekstop”, Skripsi. Bandung:Program Studi Sistem Informasi Unicersitas Komputer Indonesia.

[2]Jogiyanto. (2008). Analisis dan Desain Sistem Informasi : Pendekatan Terstruktur Teori dan Praktik Aplikasi Bisnis. Yogyakarta : Andi Offset.

[3]Sutabri, Tata. (2014). Pengantar Teknologi Informasi. Yogyakarta: Andi.

[4]Kadir, Abdul. (2014). Pengenalan Sistem Informasi Edisi Revisi. Yogyakarta : Andi.

[5]Nore, Victor Nicolas. (2013). "Perancangan Sistem Informasi Penjualan Dan Pemesanan Produk 
Vol. 2 No. 3, Agustus 2020, hlm. 146 - 151

Berbasis Web”, Skripsi. Bandung:Program Studi Sistem Informasi Universitas Widiyatama.

[6]Mutadiri, Ade Djohar. (2014). Metode Penelitian

Teknik Informatika. Yogyakarta : Deepublish.

[7]Darnis, Febriyanti dan Anita. (2018). "Website CV

Cahaya Motor Sebagai Media Promosi”, Jurnal. Vol.1.Hlm.2-3. 